\title{
EVALUASI IMPLEMENTASI PENILAIAN HASIL BELAJAR BERDASARKAN KURIKULUM 2013 OLEH GURU BAHASA INGGRIS DAN BAHASA INDONESIA DI MTS JA-ALHAQ KOTA BENGKULU
}

\author{
Heny Friantary ${ }^{1} \&$ Feny Martina ${ }^{2}$ \\ ${ }^{1}$ Tadris Bahasa Indonesia, IAIN Bengkulu \\ ${ }^{2}$ Tadris Bahasa Inggris, IAIN Bengkulu \\ JIn. Raden Patah Kelurahan Pagar Dewa, Kota Bengkulu, 65144, Indonesia \\ Email: henyfriantary30@gmail.com, feny@iainbengkulu.ac.id
}

\begin{abstract}
Abstrak
Penelitian ini bertujuan mendeskripsikan hasil evaluasi terhadap proses implementasi kurikulum 2013 dalam penilaian hasil belajar yang dilakukan oleh guru mata pelajaran bahasa Indonesia dan bahasa Inggris di MTS Ja-Alhaq Kota Bengkulu dan menjelaskan kesenjangan antara standar absolut pelaksanaan dengan implementasi penilaian hasil belajar yang dilakukan oleh guru mata pelajaran bahasa Indonesia dan bahasa Inggris di MTS Ja-Alhaq Kota Bengkulu. Metode penelitian yang digunakan yaitu metode deskriptif kualitatif. Teknik pengumpulan data dengan observasi, wawancara, dan dokumentasi. Teknik analisis data dimulai dari identifikasi data, klasifikasi data, penyajian data dan penarikan kesimpulan. Hasil penelitian menunjukkan bahwa proses implementasi penilaian hasil belajar siswa yang dilakukan oleh guru bahasa Inggris guru bahasa Indonesia belum sepenuhnya sesuai apa yang diminta oleh $\mathrm{K} 13$, penilaian aspek kompetensi pengetahuan masih didominasi dengan teknik tes tertulis, dan penilaian untuk pengukuran kompetensi keterampilan hanya dilakukan dengan teknik penilaian praktik. Kemudian, terdapat beberapa kesenjangan antara standar absolut pelaksanaan dengan implementasi penilaian hasil belajar siswa yang dilakukan oleh guru bahasa Inggris dan guru bahasa Indonesia yang menjadi subjek dari penelitian ini.
\end{abstract}

Kata kunci: evaluasi, implementasi penilaian hasil belajar, kurikulum 2013, guru bahasa Inggris dan Bahasa Indonesia

\section{EVALUATION OF LEARNING RESULTS IMPLEMENTATION BASED ON 2013 CURRICULUM BY ENGLISH AND INDONESIA TEACHERS IN MTS JA-ALHAQ BENGKULU CITY}

\begin{abstract}
The objective of this research was to describe the results of the evaluation of the 2013 curriculum implementation process in the assessment of learning outcomes conducted by Indonesian and English language subject teachers in in the Bengkulu City Ja-Alhaq MTS and explain the gap between absolute standards of implementation and the implementation of learning outcomes assessment conducted by Indonesian subject teachers and English in MTS Ja-Alhaq Kota Bengkulu. The research method used is descriptive qualitative method. Data collection techniques by observation, interviews, and documentation. The data analysis technique starts from identifying data, classifying data, presenting data and drawing conclusions. The results of the study showed


that the process of implementing student learning outcomes conducted by English teachers of Indonesian language teachers was not fully in accordance with what was requested by K13, the assessment of aspects of knowledge competence was still dominated by written test techniques, and assessment for skills competency measurement was only done with assessment techniques practice. Then, there are some gaps between the absolute standards of implementation and the implementation of student learning outcomes assessment conducted by English teachers and Indonesian teachers who are the subjects of this research.

Keywords: evaluation, implementation of learning outcomes assessment, 2013 curriculum, English and Indonesian language teachers

\section{A. Pendahuluan}

Penilaian yang kredibel dan berkualitas akan mencerminkan pendidikan dan lulusannya yang kredibel dan berkualitas. Untuk itu, lembaga pendidikan harus bisa mempraktikkan penilaian secara menyeluruh dan komprehensif dalam rangka menjelaskan pencapaian kompetensi peserta didik (Wuryani \& Irham, 2012:183). Komprehensif bermakna bahwa penilaian tidak terbatas pada penilaian pada aspek kognitif saja, tetapi juga afektif, dan psikomotor selama proses pendidikan berjalan. Menurut Fajar (2004:90), penilaian sebaiknya memiliki fungsi mengecek dan melacak kemajuan dan keterampilan serta kemampuan dari peserta didik. Oleh karena itu, guru seharusnya memiliki pemahaman yang benar tentang cara bagaimana melakukan penilaian yang kredibel dan berkualitas.

Raymond, et al. (2013:471) mengemukakan bahwa penilaian yang kredibel dam berkualitas akan berpengaruh kuat terhadap proses kegiatan pembelajaran, hasil, dan outcome-nya. Penilaian yang kredibel dan berkualitas tidak hanya melihat hasil, tetapi juga sistem penilaiannya yang kompleks mulai dari perencanaan, pelaksanaan, dan pelaporannya. Jadi, penilaian harus melihat secara keseluruhan mulai dari konteksnya, input, proses, dan output sebagai satu kesatuan secara komprehensif. Pemerintah dalam merealisasikan proses pembelajaran dan penilaian yang kerdibel dan berkualitas, tersebut, menghadirkan reformasi pembelajaran dalam format penilaian Kurikulum 2013.

Kehadiran Kurikulum 2013 diharapkan dapat manjadi solusi untuk mencapai penilaian yang kredibel dan berkualitas di sekolah. Hal tersebut dikarenakan format penilaian dengan desain yaitu: 1) pendekatan yang digunakan yaitu belajar tuntas; 2) mengukur apa yang telah bisa dilakukan oleh peserta didik; 3) dilaksanakan secara berkelanjutan atau berkesinambungan, (4) menggunakan 
teknik penilaian yang bervariatif; dan (5) acuan penilaiannya berupa kriteria dalam bentuk Kompetensi Dasar (Kemendikbud, 2013:5-6). Dalam Kurikulum 2013, format penilaian tersebut lebih dikenal dengan sebutan penilaian authentic (otentik).

Penilaian hasil belajar pada kurikulum 2013 masih tergolong baru bagi guru bahasa Inggris dan bahasa Indonesia menyebabkan banyak sekolah yang gurugurunya mengalami kebingungan dalam melakukan penilaian (Sutadji, 2014; Vermaningsih, 2014). Terlebih, yang harus melaporkan penilaian hasil belajar tersebut adalah guru per mata pelajaran itu sendiri. Pada dasarnya Kurikulum 2013 merupakan tindak lanjut dari kurikulum sebelumnya, yakni Kurikulum Berbasis Kompetensi (KBK)/Kurikulum 2006 (Mulyasa, 2013:66). Berbeda dengan Kurikulum 2006, implementasi Kurikulum 2013 menekankan pada kompetensi lulusan yang berpijak dari empat kompetensi inti yang meliputi sikap spiritual (KI 1), sikap sosial ( $\mathrm{KI} 2)$, pengetahuan ( $\mathrm{KI} 3)$, dan Keterampilan ( $\mathrm{KI} 4)$.

Berlandaskan empat kompetensi inti tersebut, Kurikulum 2013 mewajibkan seluruh mata pelajaran untuk turut serta dalam membangun, tidak hanya segi pengetahuan saja, tetapi aspek spiritual, sosial, dan keterampilan juga turut dilibatkan, yang mana penilaian hasil belajarnya juga melibatkan aspek-aspek tadi. Sebagai konsekuensinya, pendidik diharapkan mampu melakukan penilaian menyeluruh dan berkesinambungan untuk memantau perkembangan peserta didik.

Wacana yang berkembang di antara para guru, Kurikulum 2013 ini bukannya meringankan tugas guru, malah lebih merepotkan guru. Tuntutan mengenal siswa lebih mendalam dalam mengajar tidak diimbangi keterbatasan jumlah siswa yang diajarkan di kelas yang melebihi kuota jumlah kelas biasa. Hal tersebut membuat para guru kesulitan untuk melakukan penilaian aspek sikap peserta didik tidak terkecuali di kalangan guru bahasa Inggris dan guru bahasa Indonesia.

Selain itu, pada beberapa artikel penelitian (Mahmuda, 2014; Witjaksono \& Saraswati, 2013:14) menyebutkan temuan bahwa para guru merasa kurang dilatih melaksananakan Kurikulum 2013 dalam kegiatan pembelajaran. Berita yang 
dimuat oleh surat kabar Tempo pada 22 Juli 2013 memuat bahwa para guru Sekolah Menengah Atas (SMA) merasa kebingungan karena semula hanya tiga mata pelajaran saja yang menggunakan Kurikulum 2013 yaitu Matematika, Bahasa Indonesia, dan Sejarah. Namun, tiba-tiba Kurikulum 2013 diterapkan untuk semua mata pelajaran padahal guru-guru lain selain Matematika, Bahasa Indonesia, dan Sejarah belum dilatih bagaimana menerapkan Kurikulum 2013 pada mata pelajaran yang diampunya secara maksimal.

Berangkat dari masalah di atas, peneliti tertarik untuk melakukan studi evaluatif terhadap implementasi atas pelaksanaan penilaian hasil belajar menurut kurikulum 2013 yang dilakukan oleh para guru. Dalam hal ini, penelitian dilakukan di salah satu sekolah yang telah menerapkan Kurikulum 2013 di Bengkulu, yakni Sekolah Madrasah Tsanaiyah (MTS) Ja-alhaq Kota Bengkulu. Guru-guru yang dimintai keterangan dan pendapat yaitu guru bahasa Indonesia dan bahasa Inggris. Rumusan masalah dalam penelitian ini, yaitu: 1) Bagaimanakah proses implementasi kurikulum 2013 dalam penilaian hasil belajar yang dilakukan oleh guru mata pelajaran bahasa Indonesia dan bahasa Inggris di MTS Ja-Alhaq Kota Bengkulu?; 2) Bagaimanakah kemampuan guru dalam implementasi penilaian hasil belajar menurut kurikulum 2013?; dan 3) Bagaimanakah kesenjangan antara standar absolut pelaksanaan dengan implementasi penilaian hasil belajar yang dilakukan oleh guru mata pelajaran bahasa Indonesia dan bahasa Inggris di MTS Ja-Alhaq Kota Bengkulu?

Hasil penelitian ini bermanfaat sebagai sumbangan positif bagi pengembangan kurikulum dalam rangka penerapan Kurikulum 2013 di MTS JaAlhaq Kota Bengkulu dan diharapkan dapat bermanfaat sebagai bahan kajian atau informasi bagi guru bahasa di MTS Ja-Alhaq Kota Bengkulu. Kemudian, manfaat lainnya terutama bagi peneliti yaitu untuk menambahkan pengetahuan tentang kurikulum 2013 dan implementasinya dalam penilaian hasil belajar yang dilakukan oleh guru bahasa Inggris dan bahasa Indonesia di MTS Ja-Alhaq Kota Bengkulu. Bagi guru yaitu dapat dijadikan masukan kepada guru dan kepala sekolah dalam kaitannya dengan penilaian hasil belajar siswa. 


\section{B. Metode Penelitian}

Metode penelitian menggunakan metode deskriptif kualitatif. Penelitian ini dilaksanakan di MTS Ja-alhaq Kota Bengkulu, dimana kurikulum 2013 sudah di implementasikan. Sementara untuk subyek penelitian yang dimaksud dalam penelitian ini adalah satu orang guru bidang studi bahasa Indonesia dan satu orang guru bahasa Inggris yang mengajar di MTS Ja-alhaq Kota Bengkulu. Ada beberapa alasan yang melandasi pemilihan lokasi dan partisipan yang disebutkan diatas. Alasan pertama yakni berkaitan dengan aksessibilitas dengan pihak sekolah sebagaimana yang disarankan oleh Kvale (1996). Pihak peneliti memiliki akses dan bisa mendapatkan izin ke sekolah yang dituju/sekolah target. Alasan kedua yaitu karena sekolah target telah dan masih menerapkan kurikulum 2013.

Beberapa sumber data yang digunakan di dalam penelitian ini, yaitu 1) dokumen kurikulum yang digunakan sebagai pedoman pelaksanaan implementasi kurikulum khususnya pada saat proses penilaian hasil belajar siswa; 2) kepala sekolah/wakil kepala sekolah sebagai sumber data yang akan memberikan informasi mengenai kondisi sekolah dan guru-guru khususnya guru bidang studi bahasa Indonesia dan bahasa Inggris; 3) guru sebagai pelaksana kegiatan pembelajaran dan sekaligus yang bertanggung jawab atas penilaian hasil belajar yang diberikan kepada siswa di kelas; dan 4) siswa sebagai sumber data penunjang. Hal ini dilaksanakan berkenaan dengan kemampuan guru mengimplementasikan penilaian hasil belajar siswa menurut kurikulum 2013.

Data dalam penelitian ini adalah 1) proses implementasi kurikulum 2013 dalam penilaian hasil belajar yang dilakukan oleh guru mata pelajaran bahasa Indonesia dan bahasa Inggris di MTS Ja-Alhaq Kota Bengkulu; 2) kemampuan guru dalam implementasi penilaian hasil belajar menurut kurikulum 2013; dan 3) kesenjangan antara standar absolut pelaksanaan dengan implementasi penilaian hasil belajar yang dilakukan oleh guru mata pelajaran bahasa Indonesia dan bahasa Inggris di MTS Ja-Alhaq Kota Bengkulu.

Teknik pengumpulan data berupa observasi melalui catatan lapangan, daftar cek dan skala penilaian; wawancara; dan pengumpulan dokumen-dokumen yang terkait dengan implementasi kurikulum 2013. Teknik analisis data dilakukan 
secara bersamaan dengan aktifitas pengumpulan data (Sugiyono 2010:401). Kegiatan analisis data pada dilakukan secara interaktif dan terus menerus sampai tuntas (Miles \& Huberman, dalam Sugiyono, 2010:337).

Dalam penelitian ini, teknik analisis data yang digunakan yaitu deskriptif kualitatif. Ada empat langkah yang dilakukan dalam teknik analisis deskriptif kualitatif, yakni: identifikasi data, klasifikasi data, penyajian data dan penarikan kesimpulan. Pada proses identifikasi data, data yang sudah terkumpul direduksi. Data yang diperlukan dipilih, sementara data yang tidak diperlukan disisihkan. Data yang dipilih dalam kegiatan reduksi data ini merupakan hal-hal pokok yang relevan dengan fokus penelitian. Berikutnya, data yang sudah diidentifikasi digolongkan berdasarkan rumusan masalah dan/atau sub-sub masalah pada proses klasifikasi data, dan kemudian dilakukan pengodean.

Setelah pengelompokan data (klasifikasi data), data disajikan secara deskriptif kualitatif yakni penyajian temuan dengan kata-kata. Hal ini sesuai dengan pendapat dari Miles dan Huberman (dalam Sugiyono, 2010:341) mengenai penyajian data untuk penelitian kualitatif, dimana data disajikan dengan teks yang bersifat naratif. Penyajian data akan mempermudah peneliti dalam memahami yang terjadi dan merencanakan tahapan kerja selanjutnya. Tahapan terakhir yaitu penarikan kesimpulan. Pada tahapan ini, peneliti merumuskan kesimpulan berdasarkan data yang sudah diperoleh dan disajikan pada tahapan sebelumnya. Penarikan kesimpulan ini disesuaikan dengan temuan lapangan yang dikaitkan dengan rumusan masalah. Kemudian, Uji keabsahan data dilakukan dengan cara triangulasi dari beberapa sumber data yaitu observasi melalui catatan lapangan, daftar cek dan skala penilaian; wawancara; dan pengumpulan dokumen-dokumen yang terkait dengan penilaian.

\section{Hasil Penelitian dan Pembahasan}

\section{Hasil Penelitian}

a. Proses Implementasi Kurikulum 2013 dalam Penilaian Hasil Belajar

Hasil penelitian yang diperoleh dari data observasi, wawancara, dan analisis dokumen penilaian menunjukkan bahwa pada proses implementasi penilaian hasil belajar siswa yang dilakukan oleh guru bahasa Inggris maupun 
guru bahasa Indonesia, penilaian sikap nyaris tidak terlaksanakan sesuai apa yang diminta oleh $\mathrm{K} 13$, penilaian aspek kompetensi pengetahuan masih didominasi dengan teknik tes tertulis, dan penilaian untuk pengukuran kompetensi keterampilan hanya dilakukan dengan teknik penilaian praktik. Hal ini mengindikasikan bahwa guru, baik guru bahasa Inggris maupun guru bahasa Indonesia yang bersangkutan masih menerapkan dan mengutamakan sistem penilaian secara konvensional, yang mana guru masih berorientasi hanya pada hasil kognitif peserta didik.

b. Kemampuan Guru dalam Implementasi Penilaian Hasil Belajar menurut

Kurikulum 2013

Hasil penelitian yang diperoleh dari data observasi, wawancara, dan analisis dokumen penilaian menunjukkan bahwa dalam mengimplementasikan kegiatan penilaian hasil belajar siswa, guru sebetulnya memiliki panduan yang lengkap. Guru sangat dipermudah karena adanya buku pedoman guru dan buku siswa dalam melaksanakan pembelajaran K13 dikelas yang langsung dilengkapi dengan instrumen-instrumen penilaian untuk semua domain pembelajaran mulai dari kompetensi sikap, pengetahuan hingga keterampilan. Hanya saja, guru kurang memahami esensi dari konsep penilaian hasil belajar siswa menurut kurikulum 2013 sehingga hal ini terefleksi pada kemampuan guru yang tergolong kurang dalam mengimplementasikan kegiatan penilaian tersebut.

Esensi dari konsep penilaian hasil belajar kurikulum 2013 mengedepankan penilaian autentik, yang mana bentuk penilaian ini menghendaki peserta didik menampilkan sikap, menggunakan pengetahuan, dan keterampilan yang diperoleh dari pembelajaran dalam melakukan tugas pada situasi sesungguhnya. Oleh karena itu, penilaian autentik cenderung berbasis kinerja yang dilakukan secara komprehensif untuk menilai masukan, proses, dan keluaran. Dengan kata lain, penilaian autentik menilai kesiapan peserta didik, serta proses dan hasil belajar secara utuh. Hal yang sangat berbeda yang diimplementasikan oleh guru yang menjadi subjek penelitian ini, dimana guru hanya cenderung menilai hasil. 
c. Kesenjangan antara Standar Absolut Pelaksanaan dengan Implementasi

Dari hasil penelitian yang diperoleh dari data observasi, wawancara, dan analisis dokumen penilaian menunjukkan bahwa terdapat beberapa kesenjangan antara standar absolut pelaksanaan dengan implementasi penilaian hasil belajar siswa yang dilakukan oleh guru bahasa Inggris dan guru bahasa Indonesia. Pertama, kesenjangan yang paling signifikan terletak pada aspek penilaian sikap, yang mana guru beranggapan bahwa penilaian sikap tidak wajib bagi guru mata pelajaran selain PABP dan PPKn sehingga beberapa tahapan pelaksanaan penilaian sikap tidak dilaksanakan oleh guru dengan baik. Sebagai konsekuensiya, penilaian sikap yang dilakukan oleh guru terkesan tidak komprehensif. Kedua, kesenjangan yang juga signifikan nampak yaitu terletak pada penilaian aspek pengetahuan dan keterampilan.

Penilaian pada kedua aspek penilaian tersebut yang dilaksanakan oleh guru seolah hanya mengukur output dan/atau hasil saja, sementara penilaian untuk melihat kesiapan belajar dan proses belajar siswa seolah tidak diperhitungkan. Hal ini berkaitan dengan teknik penilaian yang digunakan oleh guru yang belum berbasis kinerja, dimana guru dominan menggunakan teknik tes tulis selama pembelajaran. Teknik penilaian proyek, produk, dan portofolio bahkan tidak dijumpai adanya implementasinya oleh guru bahasa Indonesia dan guru bahasa Inggris.

\section{Pembahasan}

a. Proses Implementasi K13 dalam Penilaian Hasil Belajar oleh Guru Bahasa Inggris dan Bahasa Indonesia MTs Ja-alhaq Kota Bengkulu

Implementasi penilaian hasil belajar menurut K13 yang dilakukan oleh guru bahasa Inggris dan bahasa Indonesia di MTs Ja-alhaq Kota Bengkulu dapat dilihat melalui beberapa tahapan penilaian mulai dari perencanaan, implementasi, dan pengolahan serta pelaporan hasil belajar itu sendiri yang dikaitkan dengan aspek kompetensi yang akan diukur seperti aspek kompetensi sikap, pengetahuan, dan keterampilan. Berdasarkan hasil perolehan data yang dipaparkan sebelumnya, proses penilaian hasil belajar untuk kompetensi sikap dapat disimpulkan tidak ada pelaksanaannya. Hal ini tentu akan berdampak pada kurangnya data guru ketika 
akan memperbaiki pembelajaran pada masa yang akan datang. Dalam sistem penilaian sikap sebagai bagian dari penilaian afektif dan psikomotor mempunyai peran penting untuk meningkatkan kemampuan siswa. Hal ini sesuai dengan pendapat Wuryani \& Irham (2012:183) bahwa sekolah sebagai lembaga pendidikan harus bisa mempraktikkan penilaian secara menyeluruh dan komprehensif dalam rangka menjelaskan pencapaian kompetensi peserta didik pada aspek kognitif, afektif, dan psikomotor. Dengan menilai ketiga aspek tersebut akan menunjukkan bahwa guru melaksanakn penilaian hasil belajar secara professional sehingga menghasilkan siswa yang berkualitas.

Implementasi penilaian hasil belajar menurut $\mathrm{K} 13$ yang dilakukan oleh guru bahasa Inggris dan bahasa Indonesia di MTs Ja-alhaq Kota Bengkulu dapat dilihat melalui tahapan penilaian dari aspek perencanaan, yaitu pertama, ditinjau dari segi perencanaan dilakukan oleh guru bahasa Inggris secara eksplisit menyatakan bahwa ia tidak sama sekali tidak melaksanakannya. Sementara pada guru bahasa Indonesia, perencanaan penilaian nampak pada Rencana Pelaksanaan Pembelajaran (RPP) yang disusunnya meski guru tersebut juga menyatakan bahwa pembelajaran yang dilaksanakannya tidak lagi menekankan pada penilaian sikap karena $\mathrm{KI}-1$ dan $\mathrm{KI}-2$ hanya untuk mata pelajaran PABP dan PPKn.

Pada kenyataannya, meskipun $\mathrm{KD}$ pada $\mathrm{KI}-1$ dan $\mathrm{KI}-2$ hanya ada pada mata pelajaran PABP dan PPKn, guru mata pelajaran selain PABP dan PPKN termasuk guru bahasa Inggris dan guru bahasa Indonesia tetap harus melakukan perencanaan penilaiaan sikap. Perencanaan dapat diawali dengan mengidentifikasi sikap yang ada pada $\mathrm{KI}-1$ dan $\mathrm{KI}-2$ serta sikap yang diharapkan sekolah yang tercantum di dalam kurikulum sekolah sehingga indikator untuk setiap butir sikap dikembangkan sesuai keperluan satuan pendidikan dan indikator-indikator tersebut dapat digunakan untuk semua mata pelajaran (Kemendikbud, 2016).

Yang kedua, ditinjau dari pelaksanaan penilaian hasil belajar yang dilakukan oleh guru selama proses belajar mengajar di kelas, baik guru bahasa Inggris maupun guru bahasa Indonesia tidak ada implementasinya. Meskipun guru mengakui bahwa penilaian hanya dilakukan berdasarkan pengamatan sehari-hari 
saja, namun dokumen hasil pengamatan tidak ditemukan. Guru berdalih dengan adanya revisi kurikulum terbaru, kewajiban untuk penilaian sikap tidak pada guru selain mata pelajaran PABP dan PPKn sehingga implementasi penilaian untuk sikap nyaris tidak ditemukan di setiap pembelajaran di kelas. Padahal kurikulum 2013 edisi revisi jelas menyatakan bahwa penilaian sikap untuk guru selain mata pelajaran PABP dan PPKn tetap dilaksanakan hanya saja dalam pelaksanaan penilaiannya, apa yang dinilai oleh guru tersebut hanya dari sikap siswa yang nampak saja dan hasilnya menjadi tambahan deskripsi untuk pelaporan penilaian sikap di akhir semester (Kemendikbud, 2016).

Yang ketiga, ditinjau dari pengolahan dan pelaporan hasil belajar untuk kompetensi sikap siswa, dapat dijelaskan bahwa apa yang telah dilaksanakan guru bahasa Inggris dan guru bahasa Indonesia juga belum memenuhi kriteria standar yang telah ditetapkan oleh Permendikbud 2016. Sikap dan perilaku peserta didik yang teramati oleh pendidik harusnya tercatat dalam jurnal (Kemendikbud, 2016), namun dalam hal ini hanya guru bahasa Indonesia yang mengakui melakukannya. Hal ini dikarenakan guru bahasa Indonesia yang bersangkutan berperan sebagai wali kelas, tetapi tidak demikian dengan guru bahasa Inggris. Guru bahasa Inggris memang memiliki catatan keadaan siswa yang dicatat bersamaan dalam jurnal mengajar guru, namun kolom catatan keadaan siswa jarang diisi. Kolom tersebut diisi hanya ketika ada siswa yang bolos. Padahal aturan K13 untuk pengolahan hasil penilaian sikap, tegas menyatakan bahwa semua guru wajib memiliki catatan jurnal untuk setiap peserta didik sehingga pelaporan hasil penilaian pada aspek kompetensi sikap dibuat berdasarkan rumusan deskripsi singkat sikap spiritual dan sosial dari catatancatatan jurnal setiap peserta didik tersebut (Permendikbud, 2016).

Berbeda dengan penilaian untuk aspek kompetensi sikap, proses penilaian untuk kompetensi pengetahuan peserta didik yang dilaksanakan oleh guru bahasa Inggris dan guru bahasa Indonesia dilaksanakan lengkap mulai dari tahapan perencanaan, implementasi, hingga pelaporan hasil penilaian. Di antara beberapa teknik yang ada untuk mengukur pengetahuan peserta didik, teknik tes tulis merupakan teknik paling dominan dan/atau paling sering diimplementasikan oleh guru. Sesekali guru menerapkan teknik tes lisan, hanya saja kedua guru masih 
mendapati hambatan dalam pelaksanaannya. Hambatan yang dimaksud berupa alokasi waktu yang mana teknik tes lisan seringkali membutuhkan banyak waktu dalam pelakssanaannya.

Guru dalam hal pelaksanaan penilaian kompetensi pengetahuan perserta didik tidak mendapati banyak hambatan. Terlebih buku pegangan guru memberikan petunjuk dan/atau pedoman untuk guru dalam mengimplementasikan penilaian dengan beragam teknik, baik melalui teknik penugasan, teknik tes tulisan maupun teknik tes lisan. Buku tersebut bahkan mencantumkan beberapa kisi-kisi penilaian. Oleh karena itu, guru sangat terbantu dalam melaksanakan perancangan maupun implementasi penilaian itu sendiri.

Untuk penilaian pada kompetensi keterampilan, hasil koleksi data menunjukkan bahwa salah satu teknik penilaian untuk aspek kompetensi keterampilan yang masih didapati kendala untuk implementasinya adalah teknik penilaian portofolio. Baik guru bahasa Inggris maupun guru bahasa Indonesia keduanya mengakui tidak mengimplementasikannya. Kesulitan guru dalam menyimpan kumpulan karya peserta didik menjadi alasan utama. Dalam hal ini, ruangan yang tidak memungkinkan dan tidak tersedianya loker atau lemari khusus untuk penyimpanan kumpulan karya siswa membuat guru hanya melakukan penilaian untuk hasil karya siswa dengan cara langsung dikembalikan ke siswa.

Di sisi lain, penilaian portofolio sebetulnya tidak mesti disimpan di tangan guru sepanjang semester. Penilaian portofolio dapat dipegang oleh siswa, dimana siswa diminta untuk menyimpan kumpulan karya yang sudah dinilai dan kemudian dapat diserahkan kembali ke guru ketika akhir semester. Dengan begitu, guru tetap dapat memantau perkembangan kompetensi keterampilan yang meliputi minat, prestasi dan/atau kreativitas peserta didik dalam kurun waktu tertentu. Sama halnya dengan teknik penilaian melalui portofolio, teknik penilaian melalui proyek dan produk juga tidak dijumpai adanya implementasinya.

Penilaian sikap yang nyaris tidak terlaksanakan sesuai apa yang diminta oleh $\mathrm{K} 13$, penilaian aspek kompetensi pengetahuan yang sepertinya masih didominasi dengan teknik tes tertulis serta penilaian untuk pengukuran kompetensi keterampilan yang hanya dilakukan dengan penilaian praktik mengindikasikan 
bahwa guru, baik guru bahasa Inggris maupun guru bahasa Indonesia masih menerapkan dan mengutamakan sistem penilaian secara konvensional, yang mana guru masih berorientasi hanya pada hasil kognitif peserta didik.

Satu hal yang dilewatkan oleh guru-guru yaitu prinsip penilaian K13 yang menuntut pelaksanaan penilaian autentik untuk semua aspek kompetensi, yang mana guru tidak hanya mengukur aspek kompetensi pengetahuan saja, tetapi juga mengukur kompetensi sikap sosial spiritual dan kompetensi keterampilan peserta didik. Dengan kata lain, penilaian autentik meliputi seluruh aspek domain penilaian. Dalam hal implementasinya, penilaian autentik dilakukan secara terus menerus selama kegiatan pembelajaran dan difokuskan kepada tugas-tugas kompleks atau kontekstual sehingga kompetensi atau keterampilan yang dimiliki peserta didik dapat ditunjukkan secara nyata.

\section{b. Kemampuan Guru dalam Melaksanakan Penilaian Hasil Belajar Menurut} Kurikulum 2013

Berdasarkan hasil yang didapat dari pengumpulan data, bahasan mengenai kemampuan guru bahasa Inggris dan bahasa Indonesia dalam melaksanakan penilaian hasil belajar menurut Kurikulum 2013 didiskusikan berdasarkan beberapa tahap pelaksanaan penilaian, yakni: 1) kemampuan guru dalam perencanaan penilaian; 2) kemampuan guru dalam melaksanakan penilaian; dan 3) kemampuan guru dalam pengolahan dan pelaporan hasil belajar. Pertama, dilihat dari segi kemampuan guru dalam melakukan perencanaan penilaian dapat dijelaskan bahwa guru sudah memiliki dasar pengetahuan dan panduan dalam melaksanakan kegiatan tersebut. Kegiatan merencanakan penilaian untuk aspek kompetensi sikap, pengetahuan, dan keterampilan sebetulnya bukanlah suatu hambatan bagi guru. Guru sangat dipermudah karena adanya buku pedoman guru dalam melaksanakan pembelajaran K13 di kelas sehingga tidak menjadi alasan bagi guru jika rancangan pembelajaran (RPP) yang dibuat tidak dilengkapi dengan rubrik penilaian. Hanya saja, dalam implementasinya, satu temuan yaitu RPP yang didesain oleh guru bahasa Inggris tidak sama sekali menyinggung penilaian salah satu aspek kompetensi inti K13, yakni aspek kompetensi sikap sehingga rubrik untuk penilaian sikap siswa tidak ditemukan, dan hal ini sudah diakui oleh 
guru bersangkutan. Guru bahasa Inggris beranggapan penilaian kompetensi sikap tidak lagi wajib untuk guru selain PABP dan PPKn. Berbeda halnya dengan guru bahasa Indonesia, rencana pembelajaran lengkap dengan perangkat penilaian untuk kompetensi sikap siswa.

Kecuali pada aspek kompetensi sikap, pengembangan instrumen penilaian hasil belajar Kurikulum 2013 yang dilakukan oleh guru bahasa Inggris dan bahasa Indonesia yang menjadi subjek penelitian di MTs Ja-alhaq Kota Bengkulu termasuk kategori sudah memenuhi apa yang menjadi tuntutan K13. Pengembangan instrumen penilaian dilakukan dengan membuat kisi-kisi penilaian dan indikator pada silabus.

Kedua, dari segi kemampuan guru dalam melaksanakan penilaian dapat dijelaskan bahwa guru masih belum sepenuhnya dapat memenuhi tuntutan K13 yang mana dalam implementasinya, K13 mempersyaratkan penilaian autentik (Kemendikbud, 2014). Dalam hal ini, guru masih terkategori belum melaksanakan pengukuran hasil belajar dengan penilaian autentik. Melainkan, guru-guru tersebut masih melakukannya secara konvensional. Hal ini berdasarkan hasil koleksi data, baik guru bahasa Inggris maupun guru bahasa Indonesia, keduanya fokus hanya kepada aspek kompetensi pengetahuan saja, dan pengukuran kompetensi pengetahuan siswa hanya dilakukan melalui teknik yang biasa dilakukan di kelas yakni dengan teknik tes tertulis, teknik penugasan, dan teknik tes lisan.

Untuk pengukuran kompetensi keterampilan, penilaian pada aspek ini jarang dilaksanakan dan dalam pelaksanaannya bentuk penilaiannya hanya melalui teknik penilaian praktik, yang mana penilaian jenis ini meminta peserta didik mendemonstrasikan keterampilannya dalam melakukan sesuatu. Sementara teknik penilaian proyek, produk, dan portofolio yang sangat menekankan pada proses yang menggambarkan perubahan kemampuan siswa setelah mengikuti pembelajaran tidak ada pelaksanaannya. Hal ini, seperti yang diakui oleh kedua guru, menemui banyak hambatan dalam implementasinya. Sementara Penilaian autentik merupakan penilaian yang berbasis kinerja, yang mana pengukuran hasil belajar cenderung fokus kepada tugas-tugas kompleks atau kontekstual yang 
memungkinkan peserta didik secara nyata menunjukkan kompetensi atau keterampilan yang dimilikinya (Ruslan, Fauziah, \& Alawiyah, 2016:151).

Berikutnya, dalam pengolahan hasil belajar siswa, yang pertama pada aspek kompetensi sikap, guru masih belum mampu memenuhi kriteria yang ada pada pedoman penilaian K13. Pedoman penilaian hasil belajar menurut K13 menuntut guru untuk membuat deskripsi nilai/ perkembangan sikap selama satu semester yang dimulai dari mengelompokkan catatan sikap, merumuskan deskripsi singkat sikap berdasarkan catatan sikap, dan kemudian dikumpulkan ke wali kelas untuk disimpulkan dan dilaporkan dalam bentuk predikat dan deskripsi (Kemendikbud, 2016). Dalam implementasinya, hasil deskripsi singkat yang dibuat oleh guru bahasa Inggris dan guru bahasa Indonesia yang menjadi subjek dalam penelitian ini memang berdasarkan kumpulan catatan sikap. Hanya saja, pada guru bahasa Inggris, tidak semua siswa dicatat dalam catatan sikap karena guru beranggapan pencatatan sikap hanya berdasarkan pengamatan sehari-hari dan diperuntukkan sikap siswa yang kategorinya perlu ditindak lanjuti saja.

Dalam pengolahan hasil belajar siswa pada aspek kompetensi pengetahuan dan keterampilan, guru sudah dikategorikan mampu memenuhi kriteria yang ada pada pedoman penilaian K13. Pengolahan dan penskoran yang dilakukan sudah mengacu pada pedoman penilian K13. Program remedial dilakukan oleh guru pada jam pelajarannya, namun pengayaan tidak pernah dilakukan karena belum adanya waktu senggang untuk dapat melaksanakannya.

c. Kesenjangan antara Strandar Absolut Pelaksanaan dengan Implementasi

Penilaian Hasil Belajar

Berdasarkan hasil analisis data, terdapat beberapa kesenjangan antara standar absolut pelaksanaan dengan implementasi penilaian hasil belajar siswa yang dilakukan oleh guru bahasa Inggris dan guru bahasa Indonesia. Pertama, kesenjangan antara standar absolut pelaksanaan (standar yang sesuai dengan tuntutan K13) dengan implementasi penilaian ditemukan pada aspek penilaian sikap. Secara prosedur, proses penilaian sikap siswa dimulai dari tahap perencanaan dimana pada tahap ini diawali dengan mengidenfikasi sikap yang ada pada $\mathrm{KI}-1$ dan $\mathrm{KI}-2$ serta sikap yang diharapkan oleh sekolah dan/ atau 
sesuai keperluan satuan pendidikan tersebut. Kemudian, yang perlu digarisbawahi adalah pengukuran nilai terhadap sikap spiritual dan sikap sosial peserta didik yang dilakukan oleh guru bahasa Inggris dan bahasa Indonesia adalah yang muncul secara alami selama pembelajaran di kelas maupun di luar kelas. Oleh karena itu, indikator untuk pengukuran kompetensi sikap spiritual dan sosial peserta didik tidak harus dirumuskan dari KD pada $\mathrm{KI}-1$ dan $\mathrm{KI}-2$.

Setelah menentukan indikator untuk setiap butir sikap, guru dapat memilih teknik penilaian sikap itu sendiri yakni teknik observasi, penilaian diri, dan penilaian antar teman. Sesuai dengan panduan pelaksanaan $\mathrm{K} 13$ dari Kemendikbud (2016:35), meskipun guru selain PABP dan PPKn dapat memilih teknik penilaian sikap yang ada, teknik penilaian diri dan penilaian antar teman tetap harus dilaksanakan minimal satu kali dalam satu semester. Setelah tahap perencanaan, penilaian sikap dapat dilaksanakan. Penilaian sikap ini dilaksanakan secara terus-menerus selama satu semester sehingga perkembangan sikap peserta didik dapat terpantau dengan baik. Oleh karena itu, jika di awal ada peserta didik menunjukkan sikap kurang baik, namun kemudian peserta didik tersebut telah menunjukkan perkembangan sikap, maka di dalam jurnal harus disebutkan bahwa sikap peserta didik tersebut telah konsisten menuju ke sikap baik.

Setelah tahap pelaksanaan, hasil catatan sikap siswa diolah dengan mengelompokkan catatan-catatan sikap yang ada ke dalam sikap spiritual dan sikap sosial dan kemudian dilaporkan dalam bentuk predikat dan deskripsi. Dibandingkan dengan standar pelaksanaan yang sesuai dengan pedoman pelaksanaan $\mathrm{K} 13$, dari hasil koleksi data dapat disimpulkan bahwa, dimulai dari proses perencanaan hingga pengolahan dan pelaporan nilai sikap siswa masih belum sesuai dengan tuntutan K13. Seperti yang telah dijelaskan sebelumnya, temuan ini didapati pada guru bahasa Inggris yang menjadi subjek dalam penelitian ini.

Sementara pada guru bahasa Indonesia, semua proses tahapan penilaian dilakukan sesuai dengan tuntunan K13. Namun, seperti yang diakui oleh guru bahasa Indonesia tersebut melalui wawancara, hal ini dilatarbelakangi karena 
yang bersangkutan merupakan wali kelas salah satu lokal di kelas delapan. Sebelumnya guru bersangkutan juga beranggapan bahwa untuk mata pelajaran yang diampunya itu tidak wajib melakukan penilaian sikap. Meskipun demikian, bukti yang menunjukkan adanya tahapan proses penilaian sikap siswa yang dilakukan oleh guru bersangkutan hanya pada rencana pembelajaran (RPP) yang guru tersebut desain. Selebihnya, tetap saja tidak ditemukan satu dokumen pun yang membuktikan bahwa guru tersebut melaksanakan salah satu teknik untuk penilaian kompetensi sikap siswa.

Satu hal yang begitu berbeda yakni anggapan guru bahwa, jika penilaian sikap sudah dilakukan dengan teknik observasi, teknik penilaian diri, dan antar teman tidak harus dilakukan. Sementara, pedoman pelaksanaan K13 edisi revisi dari Kemendikbud tahun 2016, jelas menyebutkan bahwa teknik penilaian diri dan antar teman tetap harus dilaksanakan minimal 1 kali selama satu semester.

Kedua, kesenjangan antara standar absolut pelaksanaan (standar yang sesuai dengan tuntutan $\mathrm{K} 13$ ) dengan implementasi penilaian ditemukan pada aspek penilaian pengetahuan. Secara prosedur, penilaian pengetahuan dimulai dari tahap perencanaan yang mana guru menentukan tujuan penilaian lebih dulu, kemudian guru menentukan bentuk penilaian yang akan dilakukan hingga memilih teknik penilaian. Setelah menentukan bentuk dan teknik, kisi-kisi untuk penyusunan instrumen penelitian mulai disusun berikut dengan pedoman penskoran. Setelah perencanaan selesai, penilaian baru dapat dilaksanakan. Hasil penilaian kemudian diolah dan dilaporkan dalam bentuk nilai, predikat, dan deskripsi capaian pengetahuan dalam rapor siswa.

Pada implementasi pengukuran untuk aspek pengetahuan siswa, baik guru bahasa Inggris maupun guru bahasa Indonesia tidak ditemukan ada kesenjangan dalam tahap perencanaan, implementasi, maupun pengolahan serta pelaporan hasil belajar siswa, baik guru bahasa Inggris dan bahasa Indonesia. Hanya saja, pada pedoman pelaksanaan $\mathrm{K} 13$ hasil penilaian menuntut untuk adanya remedial dan pengayaan kepada peserta didik.

Remedial diberikan kepada peserta didik yang belum mencapai KKM, sedangkan peserta didik yang telah mencapai KKM diberikan pengayaan. Dalam hal ini, kesenjangan yang ditemukan antara standar pelaksanaan dan apa yang 
dilaksanakan oleh guru adalah tidak adanya pengayaan yang dilakukan baik oleh guru bahasa Inggris maupun guru bahasa Indonesia. Pengayaan merupakan pendalaman dan perluasan dari kompetensi yang dipelajari dan pengayaan ini hanya dilakukan sekali dan tidak ada penilaian disini. Bentuk pelaksanaan program pengayaan dapat berupa belajar kelompok dan belajar mandiri (Kemendikbud, 2016).

Sama halnya dengan pengukuran aspek kompetensi pengetahuan, pada pengukuran untuk kompetensi keterampilan juga memiliki prosedur yang sama, dan kesenjangan yang ditemukan antara standar absolut pelaksanaan dengan apa yang diimplementasikan oleh guru juga terletak pada hasil analisis penilaian yang tidak ditindak lanjuti. Pada penilaian kompetensi pengetahuan, tindak lanjut berupa remedial tetap ada, namun pada pengukuran kompetensi keterampilan dimana teknik penilaian yang dipakai hanya berupa penilaian praktik, guru mengakui tidak ada pelaksanaan remedial. Begitu juga halnya dengan pengayaan. Hal ini dikarenakan guru tidak memiliki waktu untuk melakukan ulang penilaian praktik sebagai kegiatan remedial, yang mana penilaian praktik itu sendiri sudah memakan banyak waktu apalagi untuk melakukan kegiatan pengayaan untuk peserta didik yang memang sudah memenuhi standar KKM pembelajaran. Guru mengakui juga tidak memiliki waktu untuk melakukan pengayaan di luar jam pembelajaran. Padahal standar absolut pelaksanaan penilaian menurut $\mathrm{K} 13$, penilaian yang dilakukan harus ada tindak lanjut dari guru terlepas dari apapun teknik penilaiannya (Kemendikbud, 2016).

\section{Simpulan}

Dari hasil penelitian ini, terdapat beberapa kesimpulan penting, antara lain:

1. Pada proses implementasi penilaian hasil belajar siswa yang dilakukan oleh guru bahasa Inggris maupun guru bahasa Indonesia, dari aspek penilaian sikap hampir tidak terlaksanakan sesuai apa yang diminta oleh K13, penilaian aspek kompetensi pengetahuan masih didominasi dengan teknik tes tertulis, serta penilaian untuk pengukuran kompetensi keterampilan hanya dilakukan dengan teknik penilaian praktik. Hal ini mengindikasikan 
bahwa, baik guru bahasa Inggris maupun guru bahasa Indonesia masih menerapkan dan mengutamakan sistem penilaian secara konvensional yang masih berorientasi hanya pada hasil kognitif peserta didik.

2. Dalam mengimplementasikan kegiatan penilaian hasil belajar siswa berdasarkan Kurikulum 2013, guru bahasa Indonesia dan bahasa Inggris masih tergolong kurang mengimplementasikan kegiatan penilaian sesuai permintaan kuikulum. Hal ini dibuktikan dengan belum diterapkannya penilaian berbasis autentik oleh guru. Hal yang sangat berbeda yang diimplementasikan oleh guru yang mana guru hanya cenderung menilai hasil belajar siswa.

3. Terdapat beberapa kesenjangan antara standar absolut pelaksanaan dengan implementasi penilaian hasil belajar siswa yang dilakukan oleh guru bahasa Inggris dan guru bahasa Indonesia. Pertama, kesenjangan yang paling signifikan terletak pada aspek penilaian sikap, yang mana guru beranggapan penilaian sikap tidak wajib bagi guru mata pelajaran selain PABP dan PPKn sehingga beberapa tahapan pelaksanaan penilaian sikap tidak dilaksanakan oleh guru dengan baik. Sebagai konsekuensiya, penilaian sikap yang dilakukan oleh guru terkesan tidak komprehensif. Kedua, kesenjangan yang juga signifikan terletak pada penilaian aspek pengetahuan dan keterampilan. Penilaian pada kedua aspek penilaian tersebut yang dilaksanakan oleh guru seolah hanya mengukur output dan/atau hasil saja, sementara penilaian untuk melihat kesiapan belajar dan proses belajar siswa seolah tidak diperhitungkan. Hal ini berkaitan dengan teknik penilaian yang digunakan oleh guru yang belum berbasis kinerja dan guru dominan menggunakan teknik tes tulis selama pembelajaran. Teknik penilaian proyek, produk, dan portofolio bahkan tidak diimplementasikan oleh guru bahasa Indonesia dan guru bahasa Inggris. 


\section{Daftar Pustaka}

Fajar, Arnie. (2004). Portofolio dalam Pembelajaran IPS. Bandung: Rosda.

Kemendikbud. (2013). Panduan Teknis Penilaian di Sekolah Dasar. Jakarta: Kemendikbud.

Kemendikbud. (2014). Permendikbud Nomor 104 Tahun 2014 tentang Penilaian Hasil Belajar oleh Pendidik pada Pendidikan Dasar dan Pendidikan Menengah. Jakarta: Kementerian Pendidikan dan Kebudayaan RI.

Kemendikbud. (2016). Panduan Penilaian untuk SD. Jakarta: Kemendikbud.

Kvale, S. (1996). Interview: An Introduction to Qualitative Research Interviewing. California: SAGE Publication.

Mahmuda, A. (2014). Pengembangan Instrumen Penilaian Hasil Belajar IPA SMP/MTs Kelas VII pada Materi Karakteristik Zat Berdasarkan Kurikulum 2013. Skripsi: Prodi Pendidikan Fisika UIN Sunan Kalijada Yogyakarta.

Mulyasa, E. (2013). Standar Kompetensi dan Sertifikasi Guru. Bandung: PT Remaja Rosdakarya.

Permendikbud No. 020 Tahun 2016 tentang Standar Kompetensi Lulusan Pendidikan Dasar dan Menengah. Jakarta: Kemendikbud.

Raymond, J. E., Homer, C. S. E., Smith, R., \& Gray, J. E. (2013). Learning through Authentic Assessment: An Evaluation of a New Development in the Undergraduate Midwifery Curriculum. Nurse Education in Practice, 13(5), 471-476. doi:10.1016/j.nepr.2012.10.006

Ruslan, Fauziah, T., \& Alawiyah, T. (2016). Kendala Guru dalam Menerapkan Penilaian Autentik di SD Kabupaten Pidie. Jurnal IImiah Mahasiswa Pendidikan Guru Sekolah Dasar, 1(1), 147-157.

Sugiyono. (2010). Metoda Penelitian Pendidikan Pendekatan Kuantitatif, Kualitatif dan $R \& D$. Bandung: Alfabeta.

Sutadji, E. (2014). Pengukuran Hasil Belajar Siswa Sekolah Menengah Kejuruan: Tantangan Tenaga Pendidik dalam Melaksanakan Penilaian Menurut Kurikulum 2013. Prosiding, Konvensi Nasional Asosiasi Pendidikan Teknologi dan Kejuruan. Bandung: Universitas Pendidikan Indonesia. Diakses dari www.jurnal.upi.edu. 
Vermaningsih, D. (2014). Kemampuan Guru Mata Pelajaran Biologi Kelas X SMA se-Kecamatan Boyolali dalam Pelaksanaan Penilaian Pembelajaran pada Kurikulum 2013. Skripsi S-1. UMS: tidak diterbitkan.

Witjaksono, R. \& Saraswati, W. (2013). Implementasi Pilot-Project Kebijakan Kurikulum 2013. Buletin 10(3).

Wuryani, W., \& Irham, M. (2014). Penilaian dalam Perspektif Kurikulum 2013. Insania: Jurnal Pemikiran Alternatif Kependidikan, 19(1), 191-199. doi:10.24090/insania.v19i1.470 